This article was downloaded by: [Università della Calabria]

On: 19 December 2008

Access details: Access Details: [subscription number 772811864]

Publisher Taylor \& Francis

Informa Ltd Registered in England and Wales Registered Number: 1072954 Registered office: Mortimer House, 37-41 Mortimer Street, London W1T 3JH, UK

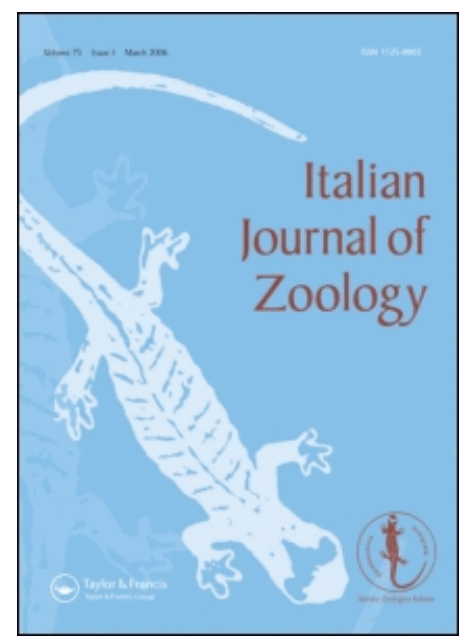

Italian Journal of Zoology

Publication details, including instructions for authors and subscription information:

http://www.informaworld.com/smpp/title content=t741771159

\title{
Suncus etruscus (Soricomorpha, Soricidae): A new species for Elba Island
} (Tuscan Archipelago, Italy)

G. Szpunar a; G. Aloise ${ }^{\text {b; }}$ M. G. Filippucci ${ }^{\mathrm{c}}$

a Dipartimento di Biologia Animale e dell'Uomo, Università di Roma "La Sapienza", Roma, Italy b Dipartimento di Ecologia, Università della Calabria, Cosenza, Italy c Dipartimento di Biologia, Università di Roma "Tor Vergata", Roma, Italy

Online Publication Date: 01 December 2008

To cite this Article Szpunar, G., Aloise, G. and Filippucci, M. G.(2008)'Suncus etruscus (Soricomorpha, Soricidae): A new species for Elba Island (Tuscan Archipelago, Italy)', Italian Journal of Zoology,75:4,445 - 447

To link to this Article: DOI: $10.1080 / 11250000802092043$

URL: http://dx.doi.org/10.1080/11250000802092043

\section{PLEASE SCROLL DOWN FOR ARTICLE}

Full terms and conditions of use: http://www.informaworld.com/terms-and-conditions-of-access.pdf

This article may be used for research, teaching and private study purposes. Any substantial or systematic reproduction, re-distribution, re-selling, loan or sub-licensing, systematic supply or distribution in any form to anyone is expressly forbidden.

The publisher does not give any warranty express or implied or make any representation that the contents will be complete or accurate or up to date. The accuracy of any instructions, formulae and drug doses should be independently verified with primary sources. The publisher shall not be liable for any loss, actions, claims, proceedings, demand or costs or damages whatsoever or howsoever caused arising directly or indirectly in connection with or arising out of the use of this material. 


\title{
Suncus etruscus (Soricomorpha, Soricidae): A new species for Elba Island (Tuscan Archipelago, Italy)
}

\author{
G. SZPUNAR ${ }^{1}$, G. ALOISE ${ }^{2} \&$ M. G. FILIPPUCCI ${ }^{3}$ \\ ${ }^{1}$ Dipartimento di Biologia Animale e dell'Uomo, Università di Roma "La Sapienza", Roma, Italy, ${ }^{2}$ Dipartimento di \\ Ecologia, Università della Calabria, Cosenza, Italy, and ${ }^{3}$ Dipartimento di Biologia, Università di Roma "Tor Vergata", \\ Roma, Italy
}

(Received 13 February 2007; accepted 21 February 2008)

\begin{abstract}
The following study contains a report regarding the first record of presence of Suncus etruscus on the island of Elba. We considered original and literature data obtained from the analysis of Barn owl (Tyto alba) pellets. Three roosts located in different areas of Elba (Marciana: Colle d'Orano-Patresi; Campo nell'Elba: La Grotta; Portoferraio: Casa Rossa) have been monitored since 1968. The presence of the Pygmy white-toothed shrew has only been observed at one roost (Casa Rossa) since 2004. We performed a biometrical analysis of 15 skull characters on 67 specimens of $S$. etruscus. From the results, we conclude that a colonization of the island by $S$. etruscus is in progress, but long-term monitoring is needed in order to control the status of the population.
\end{abstract}

Keywords: Suncus etruscus, Barn owl pellets, Elba Island, Tuscan Archipelago

\section{Introduction}

The Pygmy white-toothed shrew, Suncus etruscus (Savi, 1822), is a south Palaearctic species and in Europe it occurs in countries located around the Mediterranean Sea (Libois \& Fons 1999). In Italy, it is distributed along the peninsula (up to $1000 \mathrm{~m}$ a.s.1.), in Sicily, Sardinia and on some small islands: Asinara, Capri, Pantelleria, Lampedusa, Levanzo and Favignana, Isola Grande dello Stagnone, Lipari (see Zava \& Lo Valvo 1990; Amori 1993; Sarà 1998; Lo Valvo \& Massa 1999; Lo Cascio \& Masseti 2004). Until recently, it was considered to be absent from the whole Tuscan Archipelago (Kahmann \& Altner 1956; Toschi 1959; Sarà 1998).

This thermoxerophilic species lives in different Mediterranean habitats. It mostly occurs in open deciduous areas, but it prefers sclerophyll zones, such as stony ground, cultivated fields, mediterranean maquis and holm-oak groves (Libois \& Fons 1999; Aloise et al. 2005).

Barn owl pellet analysis is a reliable and fast method in microtheriocoenosis studies because Tyto alba is a generalist raptor, which mostly feeds on small mammals (95\%) catching about $85 \%$ of the species present in the hunting area (Contoli 1980). Furthermore, pellet analysis is useful in determining the presence of S. etruscus as this species is a common prey of the Barn owl (it could represent up to $60-70 \%$ of the captured Soricidae), and its occurrence ranks among the most common preys in several Mediterranean islands (Sarà \& Zanca 1988). Moreover, it is rarely trapped by man because of its small size (Contoli 1988).

Several Barn owl roosts located in different areas of Elba (Marciana: Colle d'Orano, Patresi; Campo nell'Elba: La Grotta; Portoferraio: Casa Rossa) have been monitored for about 35 years, making it possible to determine the recent colonization of this species on the island.

\section{Materials and methods}

Literature (Kahmann \& Niethammer 1971; Contoli et al. 1988a,b) and original data, for the same localities, were used in the present analysis.

*Correspondence: Germana Szpunar, Dipartimento di Biologia Animale e dell’Uomo, Università di Roma "La Sapienza", Via A. Borelli 50, 00161, Roma, Italy. Email: Germana.Szpunar@uniroma1.it 


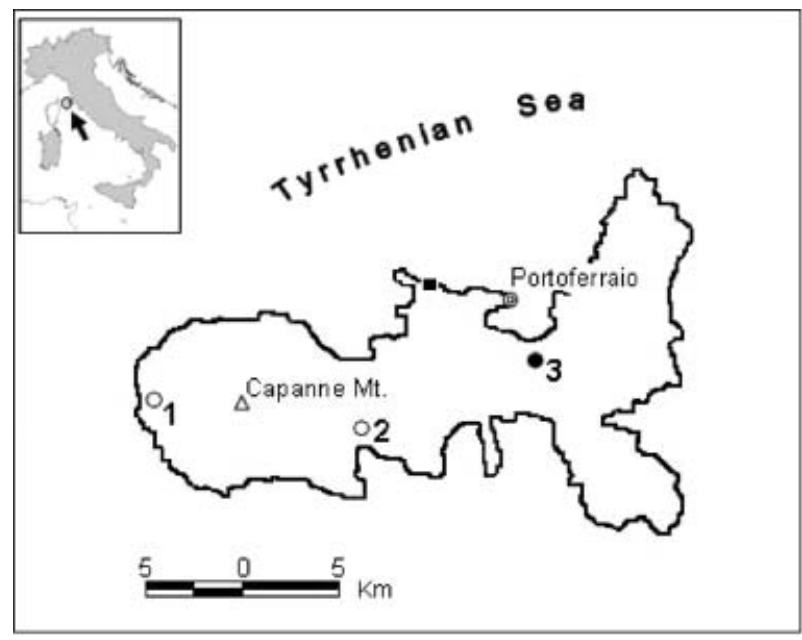

Figure 1. Localization of Tyto alba's roosts in Elba Island. 1, Patresi, Colle d'Orano (Marciana); 2, La Grotta (Campo nell'Elba); 3, Casa Rossa (Portoferraio). Distribution of Suncus etruscus: $\bullet$ full circle: present; $\bigcirc$ empty circle: absent; $\square$ square: dead specimen.

Barn owl pellets were collected in several roosting sites. The roosts are located in three different areas of Elba (Figure 1):

1. Patresi-Colle d'Orano, Marciana: data set ranges from 1968 up to 2005.

2. La Grotta, Campo nell'Elba: data are available only for three years, from 1980 to 1982, because the roosting site was renewed.

3. Casa Rossa, Portoferraio: data set ranges from 1981 to 2005.

The sites of Casa Rossa and La Grotta are characterized by higher anthropic activity, being surrounded by crops, while sclerophyllous scrubs are more characteristic of the Patresi-Colle d'Orano site.

Pellets were stored in a dry place until analysis, and were subsequently examined for the presence of prey remains and bones.

Biometrical analysis was performed on skulls of $S$. etruscus. Fifteen characters were measured by Wild Heerbrugg binocular microscope, equipped with a micrometric eyepiece (10-21×) (see: Pucek 1981; Dannelid 1990; Turni \& Müller 1996). Due to damage to the skulls, the number of specimens considered for each measurement ranges from 4 to 67 .

\section{Results}

The Pygmy white-toothed shrew has only been found in Casa Rossa (Portoferraio) since 2004. The frequency of S. etruscus (2004: 13.5\%; 2005: $7 \%$ ) is higher than C. suaveolens in the same roost
(2004: $2.1 \% ; 2005: 2.7 \%$ ) and the roost in PatresiColle d'Orano (2004: 1.5\%; 2005: 1.3\%). In the last two years, the frequency of $C$. suaveolens has decreased in Patresi-Colle d'Orano, while it has increased in Casa Rossa.

The mean values of skull characters were found to fall within the range observed in peninsular populations (Toschi 1959; Spitzenberger 1990).

\section{Discussion}

We observed a new finding of S. etruscus in 2004 in Casa Rossa, and a concurrent decrease of $C$. suaveolens in the same site (together with a second site, PatresiColle d'Orano). Moreover, in April 2004, a dead specimen of $S$. etruscus was also found in the Acquaviva locality, Portoferraio (Cristaldi in verbis), about $8 \mathrm{~km}$ from Casa Rossa. A biometrical analysis showed that the population of Elba Island is homogeneous with peninsular populations, a fact which is probably due to its recent arrival on the island.

Our data could indicate a recent colonization of the northern area of the island by $S$. etruscus. This was probably due to an involuntary anthropic introduction, because the Pygmy white-toothed shrew was found in the two sites located near Portoferraio, the main port of the island. Elba has seen a certain number of voluntary and involuntary introductions of mammals in the last 50 years. Voluntary introductions concerned Lepus europaeus in the 1960s, Sus scrofa and Dama dama in the 19601970s, Ovis musimon in the 1960s-1980s and Hystrix cristata in the 1980s (Sarà \& Morand 2002). In 1980, Vesmanis and Hutterer found a specimen of $M$. savii on Elba, but the presence of this species seems to be only due to an accidental introduction and no stable population has ever been found on the island. On the contrary, S. etruscus appears to have been successful in colonization and able to establish a population on the island. Further investigations are necessary to better define the current distribution of the Pygmy white-toothed shrew and track its possible expansion route on the island.

\section{Acknowledgements}

The authors are grateful to Prof. M. Cristaldi, M. Margiotta and M. Cagnin for their cooperation in collecting pellets and to F. Lunati, F. Paglia and S. Novelli for their support in the pellet analysis.

\section{References}

Aloise G, Brandmayr P, Cagnin M, Mazzei A, Pizzolotto R, Scalercio S. 2005. La distribuzione delle specie della fauna 
italiana in funzione degli habitat Eunis, Corine e Natura 2000. Memorie del Museo Civico di Storia Naturale di Verona, Seconda serie, Sezione Scienze della Vita 16:47-55.

Amori G. 1993. Italian insectivores and rodents: Extinctions and current status. Supplemento alle Ricerche di Biologia della Selvaggina 21:115-134.

Contoli L. 1980. Borre di Strigiformi e ricerca teriologica in Italia. Natura e Montagna 3:73-94.

Contoli L. 1988. La nicchia trofica di Allocco (Strix aluco) e Barbagianni (Tyto alba) in Italia: acquisizioni e problemi. Il Naturalista siciliano S. IV 12(suppl.):129-143.

Contoli L, Aloise G, Filippucci MG. 1988a. Sulla diversificazione trofica di Barbagianni Tyto alba e Civetta Athene noctua in rapporto al livello diagnostico delle prede. Avocetta 12: 21-30.

Contoli L, Aloise G, Filippucci MG. 1988b. Sulla nicchia trofica di Tyto alba ed Athene noctua nell'isola d'Elba (Toscana) in rapporto all'Italia tirrenica. Bullettin D' Ecologie 19: 367-373.

Dannelid E. 1990. Principal component and PLS discriminant analyses applied on skulls of European shrews of the genus Sorex (Mammalia, Soricidae). Bonner Zoologische Beiträge 41:141-156.

Kahmann H, Altner H. 1956. Die Wimperspitzmaus Suncus etruscus (Savi, 1832) auf der Insel Korsika und ihre circummediterrane Verbreitung. Säugetierkundliche Mitteilungen 6:27-81.

Kahmann H, Niethammer J. 1971. Die Waldmaus (Apodemus) von der Insel Elba. Senckenbergiana Biologica 52:381-382.

Libois R, Fons R. 1999. Suncus etruscus (Savi, 1822). In: MitchellJones AJ, Amori G, Bogdanowicz W, Kryštufek B, Reijnders PJH, Spitzenberger F, Stubbe M, Thissen JBM, Vohralik V, Zima J, editors. The atlas of European mammals. London: T \& AD Poyser. pp. 76-77.
Lo Cascio P, Masseti M. 2004. Suncus etruscus (Savi, 1822) (Mammalia, Soricidae) nell'Isola di Lipari (Arcipelago Eoliano, Tirreno meridionale). Hystrix 15:69-71.

Lo Valvo F, Massa B. 1999. Lista commentata dei vertebrati terrestri della Riserva Naturale Orientata "Isole dello Stagnone" (Sicilia). Naturalista Siciliano 23:419-466.

Pucek Z. 1981. Skull measurements used in keys. In: Pucek Z, editor. Keys to vertebrates of Poland mammals. Warszawa: Polish Scientific Publishers. pp. 52-53.

Sarà M. 1998. I Mammiferi delle Isole del Mediterraneo. Palermo: L'Epos.

Sarà M, Morand S. 2002. Island incidence and mainland population density: Mammals from Mediterranean islands. Diversity and Distributions 8:1-9.

Sarà M, Zanca L. 1988. Nicchia trofica di Tyto alba in ambienti insulari del Mediterraneo. Naturalista Siciliano 12(suppl.):173-180.

Spitzenberger F. 1990. Suncus etruscus (Savi, 1822) Etruskerspitzmaus. In: Niethammer J, Krapp F, editors. Handbuch der Säugetiere Europas. Band 3/I, Insektenfresser, Herrentiere. Wiesbaden: AULA-Verlag. pp. 375-392.

Toschi A. 1959. Insectivora. In: Toschi A, Lanza B, editors. Fauna d'Italia: Mammalia. Generalità, Insectivora, Chiroptera, Vol. IV. Bologna: Calderini editore, pp. 65-186.

Turni H, Müller EF. 1996. Unterscheidung der Spitzmausarten Sorex araneus L., 1758 und Sorex coronatus Millet, $1828 \mathrm{mit}$ Hilfe einer neuen Diskriminanzfunktion. Zeitschrift für Saugetierkunde 61:73-92.

Vesmanis IE, Hutterer R. 1980. Nachweise von Erinaceus, Crocidura und Microtus für die Insel Elba, Italien. Zeitschrift für Saugetierkunde 45:251-253.

Zava B, Lo Valvo F. 1990. First record of Suncus etruscus and notes on the bats of Pantelleria island, Italy. Mammalia $54: 661-663$ 